\title{
СУЧАСНІ ТЕНДЕНЦІЇ РОЗВИТКУ ВИРОБНИЦТВА ЗЕРНА В УКРАЇНІ ТА СВІТІ
}

\author{
Сухоставець Андрій Іванович \\ кандидат економічних наук, доцент \\ Сумський національний аграрний університет (м.Суми, Україна) \\ ORCID: 0000-0002-4101-4105 \\ 9264374@gmail.com \\ Соловей Марина Сергіївна \\ аспірант \\ Сумський національний аграрний університет (м.Суми, Україна) \\ ORCID: 0000-0003-4206-7433 \\ marusja.sol@gmail.com
}

У статті розкрито основні особливості вирощування зернових культур. У дослідженні представлено економічне значення зернових культур та тенденції їх змін у світі, а потім і на рівні України. Найбільшим виробником пшениці в світі $\epsilon$ Європейський Союз, але його перевага над іншими країнами буде продовжувати зменшуватися. Передбачається, що перше місце займуть Китай та Індія. Важливими виробниками пшениці є також країни Чорноморського регіону та США, проте найвищий приріст серед десятки кращих виробників спостерігається в Україні. Основними виробниками фуражного зерна є США, Китай та Європейський Союз. Було представлено зміни площі посівів, наборів та валових зборів. Порівнювались напрями розподілу зернових культур за останній період. Визначено напрями змін на ринку зернових культур в Україні. В Україні площа вирощування та рівень урожайності були стабільними. Ключовим напрямком розвитку ринку зерна в Україні є розширення експорту. щування.

Ключові слова: підприємництво, виробництво зернових, ринок зерна, зернове господарство, фуражне зерно, виро-

DOI: https://doi.org/10.32845/bsnau.2019.1.11

Постановка проблеми в загальному вигляді. Актуальність дослідження питань розвитку зернового ринку зумовлена тим, що зернове господарство $є$ стратегічною галуззю народного господарства, оскільки визначає продовольчу безпеку суспільства та впливає на сталий розвиток, відіграє значну роль у формуванні експортних поставок та надходження іноземної валюти у економіку країн, забезпечує зайнятість сільського населення. Удосконалення технологій виробництва зерна, створення сприятливого середовища для конкуренції за якістю продукції через диверсифікацію постачання сировини та ціни кінцевого споживача сприятиме широкомасштабному входженню країни на внутрішні та міжнародні ринки зерна. Прозоре та стабільне функціонування зернового сектору залишається ключовим фактором у забезпеченні продовольчої безпеки держави а ринково-орієнтовані реформи дають поштовх до більш лібералізованої міжнародної торгівлі.

Проблема збільшення виробництва зернових культур - стратегічна мета АПК держави, що зумовлює необхідність визначення його раціональної структури як з точки зору використання агрокліматичного потенціалу, так і щодо кон'юнктури ринку. Ринок зерна поділений на кілька сегментів: зерно, борошно, крупи, хліб та хлібобулочні вироби. Зернові культури відіграють важливу економічну роль в якості джерела доходу для виробників, як продукт харчування людини, співтворця робочих місць в сільському господарстві і в інших областях, таких як харчова промисловість та виробництво непродовольчих товарів. Зерно та похідні цих культур є основною сировиною у багатьох галузях промисловості. Можна згадати такі галузі промисловості та переробки сільськогосподарської продукції, як млини, заводи по виробництву спирту, хлібобулочні заводи, пивоварні, кондитерські заводи, а останнім часом з'явилися й такі, що пов'язані з виробництвом відновлюваних видів пального.

Зернові культури також є основним інгредієнтом кормів для тварин. Таким чином, зміни в масштабах їх виробництва $€$ важливим фактором, що впливає на економічне становище великих груп людей та країн.

Проблема пошуку пріоритетів розвитку - важлива проблема ринку зерна. Зокрема, пріоритетним вважають збільшення прибутку. Однак рішення потребує повномасштабної розробки. Крім прибутку, пріоритети можуть передбачати збільшення ринкової активності, вирішення проблем, пов'язаних із продовольчим забезпеченням та підвищення конкурентоспроможності (Diaz-Bonilla E., Ordenand D., Kwieciński A., 2014).

Аналіз останніх досліджень і публікацій. Дослідження питань пов'язаних з формуванням та динамікою ринку зерна мають достатньо багату історію та широкий ареал досліджень, як зарубіжної, так і вітчизняної наукової спільноти. Так, проблеми виробництва зернових та їх ринку розкриваються у працях Бойка В.І. (Бойко В.І., 2004), Гридіна О.В. (Гридіна О.В., 2017), Грищенко О.Ю. (Козак О.А., Грищенко О.Ю., 2016), Кушнір Н.О. (Кушнір Н.О., Славич М.М., 2017), Новицького І.В. (Новицький І.В., 2015), Саблука Р.П. (Саблук Р.П., Коноваленко О.В., 2009), Чмиря С.В. (Чмир С.В., 2007) та інших. Відзначаючи цінність результатів досліджень науковців, необхідно зазначити, що чимало питань щодо напрямів удосконалення цього сектора економіки в сучасних умовах залишаються недостатньо дослідженими, в зв'язку з постійними змінами в даному секторі економіки.

Формулювання цілей статті. Метою цього дослідження $€$ визначення тенденцій та змін в формуванні посівних площ, урожайності та розподілу зерна на зернових ринках України та світу і дослідження перспективних напрямків 
розвитку підприємництва на ринку зерна.

Методи дослідження. У дослідженні було використано такі методи дослідження як: метод аналізу, метод порівняння, емпіричний метод наукового дослідження та метод логічного узагальнення. 3 використанням цих методів було визначено основні тенденції виробництва та споживання зернових у світі та в деяких регіонах, розглянуто питання споживання та залишків зернових культур, проаналізовано ринок зернових культур.

Виклад основного матеріалу дослідження. Сільське господарство $€$ ключовим сектором економіки різних держав та стало головним джерелом надходження валюти в останні роки в Україні. Зернові культури є одним з основних сільськогосподарських продуктів і найважливішим фактором харчування людини в усьому світі. Існують дві основні категорії зернових культур - зернові, такі як пшениця, жито та кукурудза, та бобові, такі як квасоля, сочевиця, арахіс та соя. Світовий попит на кукурудзу та пшеницю зростає стрімкими темпами, а зерно стає найбільшим сировинним товаром. Приблизно 21\% світової їжі залежить від щорічних врожаїв пшениці. Загальне вживання в їжу пшениці на душу населення в усьому світі у 2017/18 роках становило 66,9 кілограмів на рік. Зростаюча частка пшениці використовується для корму для тварин в промислових країнах, а саме 45 відсотків від загального вживання в ЄС. Протягом найближчих років споживання пшениці, як очікується, збільшиться у всіх регіонах, включа- ючи країни з перехідною економікою, у міру зростання їх споживання. За прогнозами, глобальне виробництво зернових зросте на $12 \%$ до 2026 року,в основному за рахунок зростання врожайності (ФАО, 2017).

Статистика світового ринку зазвичай аналізує дві зернові групи: пшеницю та фуражне зерно. Площі вирощування та виробництва зерна представлені в таблиці 1.

Пшеницю вирощують у найбільших масштабах у країнах Чорноморського регіону, Азії, Америці та Європейському Союзі. Зберігається тенденція до збільшення площі (в середньому на рівні 1\% за досліджуваний період), хоча найвищий темп зростання був у країнах Чорноморського регіону (на 18,7\%), Африці (на 13,1\%) та Південній Азії (на7,6\%). Зниження посівної площі було зафіксовано у Північній Америці (на 18,5\%), Океанії (на 9,6\%), Східній Азії (на 8,6\%).

Що стосується площі вирощування фуражного зерна, то можна сказати що її виробництво загалом зросло у всьому світі, найшвидше зростання спостерігалось у Східній Азії (на $66,9 \%$ ) та Південній Америці (на 29,9\%). Скорочення посівних площ відбулося переважно в Європейському Союзі (на $14,6 \%$ ) та країнах Чорноморського регіону (на 8,3\%).

Негативні тенденції з вирощування фуражного зерна спостерігається в країнах ЄС на 14,6 відсотків, в Чорноморському регіоні на 8,3 відсотка та на Східному Сході, Океанії та Північні Америці на 3,2 відсотка, 3,7 відсотка та 3,0 відсотка відповідно.

Таблиця 1

Площа вирощування пшениці та фуражного зерна в регіонах світу

\begin{tabular}{|c|c|c|c|c|c|}
\hline \multirow[b]{2}{*}{ Назва регіону } & \multicolumn{5}{|c|}{ Площа вирощування [млн. га] } \\
\hline & $2000 p$ & $2005 p$ & 2010p. & $2018 p$ & $\begin{array}{l}\text { 2018p. до 2000p. } \\
(+/-), \%\end{array}$ \\
\hline \multicolumn{6}{|c|}{ Пшениця } \\
\hline Чорноморський регіон & 38,4 & 44,5 & 47,2 & 45,6 & 18,7 \\
\hline Південна Азія & 39,5 & 37,9 & 40,5 & 42,5 & 7,6 \\
\hline Північна Америка & 32,3 & 29,7 & 27,6 & 26,3 & $-18,5$ \\
\hline Східна Азія & 26,8 & 23,0 & 24,5 & 24,5 & $-8,6$ \\
\hline$\epsilon C$ & 24,7 & 24,7 & 24,1 & 23,7 & $-4,0$ \\
\hline Середній Схід & 17,9 & 19,0 & 17,5 & 17,4 & $-2,8$ \\
\hline Океанія & 12,1 & 12,5 & 13,5 & 11,2 & $-9,6$ \\
\hline Африка & 8,4 & 9,7 & 9,2 & 9,5 & 13,1 \\
\hline Південна Америка & 9,1 & 9,1 & 8,9 & 9,1 & 0,0 \\
\hline \multicolumn{6}{|c|}{ Фуражне зерно } \\
\hline Африка & 74,3 & 81,3 & 88,4 & 93,9 & 26,3 \\
\hline Східна Азія & 26,6 & 28,9 & 37,2 & 44,4 & 66,9 \\
\hline Північна Америка & 42,6 & 41,0 & 41,2 & 41,3 & $-3,0$ \\
\hline Південна Азія & 32,1 & 30,9 & 30,1 & 32,1 & 0,0 \\
\hline Південна Америка & 24,4 & 22,8 & 25,0 & 31,7 & 29,9 \\
\hline$\epsilon C$ & 33,4 & 32,1 & 28,9 & 28,5 & $-14,6$ \\
\hline Чорноморський регіон & 28,9 & 26,1 & 24,3 & 26,5 & $-8,3$ \\
\hline Південно-Східна Азія & 8,2 & 8,3 & 9,0 & 8,7 & 6,1 \\
\hline Середній Схід & 6,1 & 6,9 & 6,2 & 5,9 & $-3,2$ \\
\hline Океанія & 5,4 & 7,5 & 5,4 & 5,2 & $-3,7$ \\
\hline
\end{tabular}

Джерело: Розраховано за даними (FAO 2017, 2017).

Проте площа вирощування сільськогосподарських культур - не найкращий показник їх важливості. Для подаль- шого аналізу ми розглянемо валовий збір врожаю, який представлений у таблиці 2. 
Таблиця 2

Валовий збір пшениці та фуражного зерна в регіонах світу

\begin{tabular}{|c|c|c|c|c|c|}
\hline \multirow[b]{2}{*}{ Назва регіону } & \multicolumn{5}{|c|}{ Валовий збір [млн. т] } \\
\hline & $2000 p$ & $2005 p$ & 2010p. & $2018 p$ & $\begin{array}{l}\text { 2018p. до 2000p. } \\
(+/-), \%\end{array}$ \\
\hline \multicolumn{6}{|c|}{ Пшениця } \\
\hline$\epsilon C$ & 130,7 & 136,4 & 137,7 & 136,8 & 4,6 \\
\hline Східна Азія & 100,3 & 98,3 & 115,7 & 132,3 & 31,9 \\
\hline Південна Азія & 103,8 & 96,8 & 110,9 & 131,7 & 26,8 \\
\hline Чорноморський регіон & 56,8 & 77,5 & 67,9 & 110,7 & 94,8 \\
\hline Північна Америка & 87,2 & 83,1 & 83,4 & 83,1 & $-4,7$ \\
\hline Середній Схід & 35,9 & 43,9 & 38,3 & 38,5 & 7,2 \\
\hline Південна Америка & 20,3 & 20,6 & 26,7 & 28,4 & 39,9 \\
\hline Афррика & 14,5 & 20,7 & 21,7 & 27,6 & 90,3 \\
\hline Океанія & 22,4 & 25,4 & 27,7 & 17,3 & $-22,7$ \\
\hline \multicolumn{6}{|c|}{ Фуражне зерно } \\
\hline Північна Америка & 297,2 & 323,5 & 352,6 & 405,8 & 36,5 \\
\hline Східна Азія & 116,4 & 147,9 & 197,3 & 265,5 & 128,0 \\
\hline Південна Америка & 78,1 & 78,8 & 110,1 & 167,3 & 114,2 \\
\hline$\epsilon C$ & 136,7 & 144,9 & 137,9 & 140,9 & 3,1 \\
\hline Афррика & 77,7 & 92,5 & 122,2 & 139,2 & 79,1 \\
\hline Чорноморський регіон & 44,6 & 48,4 & 40,5 & 85,4 & 91,5 \\
\hline Південна Азія & 35,2 & 40,3 & 51,9 & 59,3 & 68,4 \\
\hline Південно-Східна Азія & 17,1 & 20,0 & 26,5 & 30,1 & 76,0 \\
\hline Середній Схід & 14,8 & 21,8 & 19,5 & 18,6 & 25,6 \\
\hline Океанія & 11,6 & 14,8 & 12,4 & 10,9 & $-6,0$ \\
\hline
\end{tabular}

Джерело: Розраховано за даними (FAO 2017, 2017).

Одним з найбільших виробників пшениці в світі $€$ незмінно Європейський Союз, але за останні роки країни Азії наростили виробництво зернових, головним чином Китай та Індія (із середньорічним темпом зростання на рівні 3,6-3,7\%), за рахунок нових підходів до ротації землі, зміни площ виробництва пшениці та підвищення врожайності. Найбільш швидке збільшення валового виробництва зерна спостерігається в країнах Чорноморського регіону (на 94,8\%за досліджуваний період), Африці (на 67,8), Південній Америці (на 39,7 \%) та Східній Азії (на 31,9\%). Ці регіони вплинули на збільшення світових урожаїв на 23,3\% (у ЄС лише 4,5\%). Загалом виробництво пшениці збільшилось у всіх регіонах, крім Океанії (-20,5\%) та Північної Америки (- 2,9\%).В Австралії, Канаді та Сполучених Штатах зменшення виробництва пояснюється головним чином скороченням посівних площ під впливом зниження цін.

Аналізуючи виробництво фуражних зернових, можна сказати, що основними виробниками є Північна та Південна Америка, Східна Азія та Європейський Союз. Найшвидше зростання виробництва спостерігається в Східній Азії (на 128\%3а досліджуваний період),Південній Америці (на114,2\%), та країнах Чорноморського регіону (на 91,5\%). Зниження врожаю цих культур зафіксовано в країнах Океанії через складні погодні умови та посуху. Світовий приріст склав 59,5\%, на відміну від пшениці, де зростання спостерігалося на рівні $16,3 \%$.

За прогнозами експертів, традиційні виробники зернових, такі як США, Канада, Австралія та Європейський Союз, збільшать виробництво зернових до 2022 року, але країни, що розвиваються, Азія, Африка та Латинська Америка, також становлять близько 60\% приросту. Основний приріст припадає на частку кукурудзи.

Найбільш важливі виробники пшениці та фуражного зерна представлені в таблиці 3. Найбільшим виробником пшениці в світі $є$ Європейський Союз, але його перевага перед іншими країнами швидко зменшується. Зі збільшенням виробництва в ЄС на рівні лише 4,6\%, цей показник спостерігається в Китаї на рівні $31,9 \%$ та 30,6\% в Індії. Важливими виробниками пшениці $€$ країни Чорноморського регіону та США, проте найбільше зростання серед першої десятки виробників пшениці було зафріксовано в Україні (на 128,2\% порівняно з 16,3\%, що відбулося у світі). Найменший прогрес був у Австралії (-23,5\%), США (-15,5\%)та Туреччині (-4,7\%).

Найбільшими виробниками фруражного зерна є США, Китай та Європейський Союз. 
Таблиця 3

Основні виробники пшениці та фуражного зерна у світі

\begin{tabular}{|c|c|c|c|c|c|}
\hline \multirow[b]{2}{*}{ Країна } & \multicolumn{5}{|c|}{ Валовий збір [млн. т] } \\
\hline & 2000p. & $2005 p$ & 2010p. & $2018 p$ & $\begin{array}{c}\text { 2018p. до 2000p. } \\
(+/-), \%\end{array}$ \\
\hline \multicolumn{6}{|c|}{ Пшениця } \\
\hline$\epsilon C$ & 130,7 & 136,4 & 137,7 & 136,8 & 4,6 \\
\hline Китай & 99,6 & 97,4 & 116,1 & 131,4 & 31,9 \\
\hline Індія & 76,3 & 68,6 & 80,8 & 99,7 & 30,6 \\
\hline$P \Phi$ & 34,4 & 47,6 & 41,5 & 70,9 & 106,1 \\
\hline США & 60,6 & 57,2 & 60,1 & 51,2 & $-15,5$ \\
\hline Канада & 26,5 & 25,7 & 23,2 & 31,7 & 19,6 \\
\hline Пакистан & 21,1 & 21,6 & 23,3 & 25,4 & 20,3 \\
\hline Україна & 11,0 & 18,7 & 16,9 & 25,1 & 128,2 \\
\hline Туреччина & 21,0 & 21,5 & 19,6 & 20,0 & $-4,7$ \\
\hline Аргентина & 15,9 & 12,5 & 16,1 & 19,3 & 21,3 \\
\hline Австралія & 22,1 & 25,1 & 27,4 & 16,9 & $-23,5$ \\
\hline \multicolumn{6}{|c|}{ Фуражне зерно } \\
\hline США & 272,9 & 298,5 & 330,1 & 379,7 & 39,1 \\
\hline Китай & 113,9 & 147,4 & 196,9 & 265,1 & 132,7 \\
\hline$\epsilon C$ & 143,9 & 151,9 & 143,8 & 147,8 & 2,7 \\
\hline Бразилія & 43,6 & 44,8 & 59,6 & 95,2 & 118,3 \\
\hline Аргентина & 20,2 & 18,4 & 31,1 & 59,1 & 192,5 \\
\hline Індія & 31,1 & 34,1 & 43,1 & 46,7 & 50,1 \\
\hline Україна & 13,8 & 18,7 & 21,9 & 44,5 & 222,4 \\
\hline $\mathrm{P \Phi}$ & 28,8 & 27,4 & 16,6 & 34,9 & 21,2 \\
\hline Мексика & 24,1 & 25,7 & 31,0 & 32,9 & 36,5 \\
\hline Канада & 24,2 & 24,9 & 22,6 & 26,2 & 8,2 \\
\hline
\end{tabular}

Джерело: Розраховано за даними (FAO 2017, 2017).

Найбільший приріст виробництва фуражного зерна спостерігається в Україні (на 222,4\%), Аргентині (192,5\%),Китаї $(132,7 \%)$, та Бразилії (118,3\%), порівняно зі світовим зростанням на 59,5\%. Зміни у виробництві зерна вплинули на їх споживання (таблиця 4).
Так само, як і продуктивність, споживання фуражних зернових $(87,6 \%)$ росте швидше, ніж пшениці $(53,4 \%)$. Що стосується фруражного зерна,тут чітко переважає зростання споживання та промислового використання (87,6\%) порівняно із запасами $(70,3 \%)$.

Таблиця 4

Світове виробництво, споживання та запаси пшениці та фуражного зерна

\begin{tabular}{|l|c|c|c|c|c|}
\hline \multicolumn{1}{|c|}{ Показник, [млн. т.] } & 2000 & 2005 & 2010 & 2018 & $\begin{array}{c}2018 \text { до 2000 } \\
(+/-), \%\end{array}$ \\
\hline $\begin{array}{l}\text { Пшениця } \\
\text { Виробництво }\end{array}$ & 585,6 & 626,9 & 652,5 & 733,9 & 25,3 \\
\hline Споживання & 486,7 & 621,5 & 654,9 & 746,8 & 53,4 \\
\hline Запаси на кінець періоду & 234,0 & 174,1 & 211,6 & 286,7 & 22,5 \\
\hline $\begin{array}{l}\text { Фуражне зерно } \\
\text { Виробництво }\end{array}$ & 876,1 & 995,4 & 1142,0 & 1416,8 & 61,7 \\
\hline Споживання & 761,7 & 1000,1 & 1163,6 & 1429,3 & 87,6 \\
\hline Запаси на кінець періоду & 241,3 & 192,0 & 195,9 & 411,1 & 70,3 \\
\hline
\end{tabular}

Джерело: Розраховано за даними (FAO 2017, 2017).

Головним фактором приросту світового споживання пшениці в порівнянні 3 попередніми періодами стало поступове збільшення продовольчого споживання. Це обумовлено стійким зростанням споживання зерна, особливо в країнах Північної Африки, Перської затоки, Азії. Середній обсяг споживання зернових у світі зберігається на стабільному рівні, що становить близько149 кг. на душу населення.

Товарні запаси пшениці в світі на кінець 2018 сільськогосподарського року збільшуються п'ятий рік поспіль, що обумовлюється, головним чином, збільшенням запасів в Китаї. Згідно з прогнозами, загальний обсяг споживання пшениці в продовольчих цілях підвищуватиметься пропорційно приросту світового населення, проте скорочення використання пшениці в кормових цілях пов'язане із наявністю про- позиції більш дешевого фуражного зерна з боку ряду найбільших постачальників. Фактором впливу на підвищення обсягів споживання фуражного зерна стало збільшення споживання кукурудзи і ячменю. Прогнозується інтенсифікація світового споживання кукурудзи, перш за все у країнах Африки - в середньому на $3 \%$ на рік.

На аграрному ринку зернові культури зберігають свої лідируючі позиції в експорті, переробці і внутрішньому споживанні, підтверджуючи їх стратегічне значення для забезпечення продовольчої та економічної безпеки в країні. За сучасних умов у найближчий час розвиток експортного потенціалу зернового підкомплексу має стати пріоритетним напрямом зовнішньоекономічної політики в Україні. Виробництво зерна $€$ одним з ключових експортно-орієнтованих секторів аграр- 
ного виробництва, одним з основних джерел прибутку в іноземній валюті (Васільєва Н., Вініченко І., Катан І., 2015). Кліматичні та екологічні умови в Україні особливо підходять для виробництва зернових культур. Площі під зерновими культурами в Україні представлені в Таблиці 5.

Посівна площа зернових культур в Україні у 1990-2018 роках

Таблиця 5

\begin{tabular}{|c|c|c|c|c|c|}
\hline \multirow{2}{*}{ Рік } & Посівна площа культур сільськогосподар- & \multicolumn{3}{|c|}{ з яких [\%] } \\
\cline { 3 - 6 } & ських [млн. га] & Зернові культури & Пшениця & Жито & Кукурудза \\
\hline 1990 & 32,4 & 45,0 & 23,4 & 1,6 & 3,8 \\
\hline 1995 & 30,9 & 45,7 & 17,8 & 2,0 & 3,8 \\
\hline 2000 & 27,1 & 50,2 & 20,7 & 2,5 & 5,0 \\
\hline 2005 & 26,0 & 57,6 & 25,6 & 2,4 & 6,6 \\
\hline 2010 & 26,9 & 56,0 & 23,9 & 1,1 & 10,0 \\
\hline 2015 & 26,9 & 54,8 & 25,5 & 0,6 & 15,3 \\
\hline 2018 & 27,6 & 53,8 & 23,95 & 0,54 & 16,6 \\
\hline \multicolumn{2}{|l|}{ Джерело: Розраховано за даними (FAO 2017, 2017). } \\
\hline
\end{tabular}

З 1990 року в Україні посівні площі дещо зменшилися з більш ніж 32,0 до 27,6 млн. га. В останні роки, однак, посівні площі вдалося стабілізувати. Структура посіву також змінювалася в піковий період, частка зернових культур становила близько $57,6 \%$.

У той же час змінилася і структура зернових культур за рахунок зменшення частки сортів із нижчою урожайністю, таких як жито,на користь більш продуктивних культур, наприклад, кукурудзи, що було дуже важливим елементом, частка якої в площі посівів зросла за період 1990-2018 рр. з 3,8\% до $16,6 \%$, і ця тенденція зростає.

Одним із елементів, що характеризують виробництво сільськогосподарських культур, $є$ валовий збір продукції. Його рівень в Україні представлений в таблиці 6.

Таблиця 6

Валовий збір зерна в Україні у 2000 - 2018 роках

\begin{tabular}{|l|c|c|c|c|c|}
\hline \multirow{2}{*}{ С/г культура } & \multicolumn{5}{|c|}{ Валовий збір зернових [тис. т.] } \\
\cline { 2 - 6 } & 2000 & 2005 & 2010 & 2015 & 2018 \\
\hline Пшениця & 10197,0 & 18699,2 & 16851,3 & 26532,1 & 24605,8 \\
\hline Жито & 969,3 & 1054,2 & 464,9 & 391,1 & 393,8 \\
\hline Ячмінь & 6872,1 & 8975,1 & 8484,9 & 8288,4 & 7349,1 \\
\hline Овес & 881,4 & 790,7 & 458,5 & 488,5 & 418,5 \\
\hline Просо & 426,1 & 140,6 & 117,1 & 213,2 & 80,5 \\
\hline Гречка & 480,6 & 274,7 & 133,7 & 128,1 & 137,0 \\
\hline Рис & 89,7 & 93,0 & 148,0 & 62,5 & 69,2 \\
\hline Кукурудза & 3848,1 & 7166,6 & 11953,0 & 23327,6 & 35801,1 \\
\hline Бобові & 652,0 & 757,5 & 592,3 & 502,1 & 954,6 \\
\hline Інші & 42,7 & 63,9 & 67,2 & 192,2 & 246,9 \\
\hline Разом & 24459,0 & 38015,5 & 39270,9 & 60125,8 & 70056,5 \\
\hline
\end{tabular}

Джерело: Розраховано за даними (OECD/FAO. 2019, 2019).

Протягом періоду дослідження спостерігається загальне збільшення врожаю в 2,8 рази, в той час як напрям i темп змін варіюються. Найбільш помітним було збільшення врожаю кукурудзи(у 9,3 рази), яка набуває все більшого значення в сільському господарстві України, та пшениці (у 2,4 рази). Зростає врожайність бобових (46,4\%). Проте не всі зернові культури відзначились позитивною динамікою. Щодо ячменю, скорочення посівних площ у порівнянні з попередніми роками (на13\%)вкупі з несприятливими погодними умовами стали причиною зниження виробництва відносно пікового періоду (2015/2016маркетинговий рік).

Загальний аналіз динаміки виробництва зернових свідчить про те, що показник врожайності ключових культур в
Україні продовжує зростати. Причина зростання урожайностів застосуванні більш ефективних технологій виробництва зернових, а також у розширюванні обсягів зрошування полів. Отже за умови якісного підходу до фінансування виробництва сільгоспкультур, Україну очікує позитивна тенденція до збільшення виробництва і експорту зерна, що може значно покращити позиції України в світовій торгівлі (Gorbachev M., 2019).

Лідером як на внутрішньому, так і зовнішньому ринку зернових є кукурудза завдяки високій врожайності та стійкості до погодних умов, а також високому експортному потенціалу. У таблиці 7 представлений баланс зернових на українському ринку. 
Таблиця 7

Динаміка балансу зернових за 2014/15-2018/19MP

\begin{tabular}{|c|c|c|c|c|c|}
\hline $\begin{array}{r}\text { Баланс зернових, тис. т } \\
\end{array}$ & $2014 / 15$ & $2015 / 16$ & $2016 / 17$ & $2017 / 18$ & $2018 / 19^{*}$ \\
\hline Запаси на початок року & 6831,4 & 8981,0 & 6044,1 & 6453,8 & 6304,9 \\
\hline Збиральні площі, млн. га & 14,63 & 14,64 & 14,34 & 14,56 & 14,78 \\
\hline Виробництво & 63859,3 & 60125,8 & 66088,0 & 61916,7 & 70056,5 \\
\hline Урожайність, ц/га & 43,7 & 41,1 & 46,1 & 42,5 & 47,4 \\
\hline Імпорт & 196,8 & 210,7 & 222,6 & 278,6 & 237,1 \\
\hline Експорт & 35178,5 & 39923,8 & 45211,7 & 40955,7 & 49720,0 \\
\hline Пропозиція & 70888 & 69318 & 72355 & 68649 & 76342 \\
\hline Фонд споживання & 6207,9 & 5834,7 & 5684,6 & 5577,6 & 5454,1 \\
\hline Посівний матеріал & 2236,4 & 2325,1 & 2217,3 & 2220,9 & 2264,0 \\
\hline Фуражне споживання & 14933,4 & 12728,1 & 10226,1 & 10609,6 & 10789,9 \\
\hline Промислова переробка & 1294,1 & 1056,6 & 1258,1 & 1577,0 & 1188,0 \\
\hline Втрати & 2056,1 & 1405,1 & 1303,1 & 1403,3 & 1765,6 \\
\hline Запаси на кінець року & 8981,0 & 6044,1 & 6453,8 & 6304,9 & 6964,6 \\
\hline
\end{tabular}

Джерело: Розраховано за даними (Статистичний щорічник. Рослинництво України 2018, 2019).

*За прогнозом Продовольчої і сільськогосподарської організації Об'єднаних Націй

Ринкова ситуація в Україні характеризується відносною стабільністю щодо валового збору й експорту зернових, хоча з подальшим скороченням запасів на кінець року. Наявні високі показники врожайності повністю задовольняють потреби внутрішнього попиту, даючи змогу забезпечити продовольчу безпеку держави, та генерують ресурс для експорту. За попередніми даними у 2018/19 МР виробництво зернових буде на 7,9 млн. тонн більше ніж у 2017/18 МР і досягне майже 70 млн. тонн. Найбільше зросте виробництво кукурудзи. Разом зі зростанням валового виробництва, обсяг експорту в 2018/19 МР очікується на рівні 47,5 млн. тонн, що на 6,5 млн. тонн перевищує минулорічні показники. Фуражне споживання зернових зросте на 11\% або 1,2 млн. т, знову ж таки, в основному за рахунок кукурудзи.

На внутрішні потреби залишається приблизно 23 млн. т зерна, тому майже весь приріст врожаю призначений на експорт. Експорт у середньому становить $66,5 \%$ від отриманого врожаю. Це також пов'язано зі збільшенням сальдо зовнішнього торгівлі зерном (наприклад, у 2014/15 рр. країна експортувала на 35,0 млн. тонн зерна більше, ніж імпортувала, а у 2018/19 рр. експорт перевищив імпорт вже на 49,0 млн. тонн) (Посевные площади под пшеницу в 2019 г. вырастут до 6,6 млн га., 2019). Україна - одна з небагатьох країн світу, яка, враховуючи наявні ресурси, може збільшити виробництво зернових культур, наростити експортні потужності та забезпечити світові потреби. Це явище є позитивним, оскільки призводить до збільшення частки міжнародної торгівлі України. 3 урахуванням поступового зростання світових цін на сільгосппродукцію, це дає підстави для збереження високих показників прибутковості аграрного бізнесу.

Висновки 3 проведеного дослідження і перспективи подальших розвідок. Проведене дослідження виявило основні тенденції розвитку ринку зерна:

1. Пшеницю вирощують переважно в країнах Чорноморського регіону, Азії, Північній та Південній Америці та Європейському Союзі, але найвища динаміка збільшення посів- них площ засріксована у країнах Чорноморського регіону, Африці та Південній Азії в Південній Азії. Площа вирощування кормового зерна зросла в Східній Азії та Південній Америці. Найбільшим виробником зерна є Європейський Союз, але країни Азії також наростили виробництво зернових. Найвищі темпи приросту врожаю були в країнах Чорноморського регіону, Африці, Південній Америці та Східній Азії. Виробництво пшениці збільшилось у всіх регіонах, крім Океанії та Північної Америки. Що стосується фуражного зерна, то найбільшими виробниками є Північна Америка, Східна Азія та Європейський Союз. Більш високі темпи виробництва зерна зафіксовані у Південній Америці, Східній та Південно-Східній Азії.

2. Найбільшим виробником пшениці в світі є Європейський Союз, але його перевага над іншими країнами буде продовжувати зменшуватися. Передбачається, що перше місце займуть Китай та Індія. Важливими виробниками пшениці $€$ також країни Чорноморського регіону та США, проте найвищий приріст серед десятки кращих виробників спостерігається в Україні. Основними виробниками фуражного зерна $є$ США, Китай та Європейський Союз. Найбільше зростання рентабельності, однак, було зареєстровано в Україні, Бразилії, Аргентині та Китаї. Найбільше збільшення споживання спостерігається щодо кормового зерна, порівняно з пшеницею.

3. В Україні зросла тенденція до валового виробництва зерна протягом останнього періоду і прогнозується на наступні 10-15 років. У структурі зернових культур зросла частка більш продуктивних рослин, таких як кукурудза, з одночасним зниженням врожаю жита та зернових сумішей. Відповідно до збільшення обсягів виробництва також збільшився експорт зерна з України, що збільшить приплив валютних коштів у країну. Зерновий підкомплекс має значний потенціал розвитку, який покращить економічну ситуацію не лише у сільському господарстві, а й в економіці країни загалом. Однак нарощування потенціалу зернового підкомплексу та його подальший розвиток мають відбуватися в умовах розробленої державної політики щодо підтримки аграрного сектору та зокрема зернового сектору.

\section{References:}

1. Diaz-Bonilla E., Ordenand D., Kwieciński A. (2014). "Enabling Environment for Agricultural Growth and Competitiveness: Evaluation, Indicators and Indices", OECD Food, Agriculture and Fisheries Papers, No. 67, OECD Publishing, Paris. 76 p.

2. Boyko VI (2004) Toward a problem of grain market formation. APK economy. No 3. P. 35-38.

3. Gridin OV (2017) Grain subcomplex of Ukraine: current state, current problems and prospects. Actual problems of innovative 
economy. No. 1. pp. 21-27.

4. Kozak OA, Grischenko OY (2016) Development of the grain industry of Ukraine at the present stage. APK economy. No 1. P. 38-47. Available at: http://nbuv.gov.ua/UJRN/E_apk_2016_1_7. (Accessed 01.02.2019).

5. Kushnir NO, Slavic MM (2017) Current Trends in Ukraine's Development in the Global Grain Market. Scientific Bulletin of Uzhgorod National University. Series: International Economic Relations and the World Economy. No. 15 (2). P. 125-128. Available at: http://nbuv.gov.ua/UJRN/Nvuumevcg_2017_15(2)_29. (Accessed 01.02.2019).

6. Novitsky IV (2017) Theoretical Foundations of Economic Relations of the Subjects of the Grain Subcomplex. Scientific Bulletin of Uzhgorod National University. Series: International Economic Relations and the World Economy. No. 13 (2). P. $39-43$. Available at: http://nbuv.gov.ua/UJRN/Nvuumevcg_2017_13(2)_11. (Accessed 01.02.2019).

7. Sabluk RP, Kovalenko OV (2009) Current Trends in Global Grain Trade. APK economy. No. 9. P. 84-88.

8. Chmir S.M. (2007) Formation and development of the Ukrainian grain market: a monograph. K.: Agrarian Science. 376 p.

9. FAO. 2017. (2017). The future of food and agriculture - Trends and challenges. Food and Agriculture Organization of the United Nations. Rome. 163 p.

10. Vasylieva N., Vinichenko I., Katan L. (2015) Economic and mathematical evaluation of Ukrainian agrarian market by branches. Economic Annals-XXI. № 9-10. pp. 41-44.

11. OECD/FAO. 2019. OECD-FAO Agricultural Outlook 2019-2028. OECD Publishing, Paris/Food and Agriculture Organization of the United Nations, Rome. 2019. Available at: https://doi.org/10.1787/agr_outlook-2019-en. (Accessed 01.02.2019).

12. Statistical Yearbook. Crop of Ukraine 2018. State Statistics Service of Ukraine. Kiev. 2019. 220 p. Available at: http://www.ukrstat.gov.ua/druk/publicat/kat_u/2019/zb/04/zb_rosl_2018.pdf. (Accessed 01.02.2019).

13. Gorbachev M. What are the prospects for Ukraine's grain market by 2030 ? Available at: https://delo.ua/business/jakiperspektivi-zernovogo-rinku-ukrajini-do-2030-roku-344436. (Accessed 01.02.2019).

14. Statistical publication "Agriculture of Ukraine" 2018 (2019) State Statistics Service of Ukraine. Kiev. 235 p. Available at: http://www.ukrstat.gov.ua/druk/publicat/kat_u/2019/zb/09/Zb_sg_2018\%20.pdf. (Accessed 01.02.2019).

15. The acreage under wheat will grow to 6.6 million hectares in 2019. Available at: https://latifundist.com/novosti/43497-posevnye-ploshchadi-pod-pshenitsu-v-2019-g-vyrostut-do-65-66-mln-ga. (Accessed 01.02.2019).

Andrii Sukhostavets, PhD, Associate Professor, Sumy National Agrarian University (Sumy, Ukraine)

Maryna Solovey, postgraduate, Sumy National Agrarian University (Sumy, Ukraine)

Current trends of grain production development in Ukraine and the world

The article reveals the key features of grain crops cultivation. The study presents an economic importance of cereal crops and tendencies of their changes in the world, and then on the level of Ukraine.

Wheat is grown mainly in the countries of the Black Sea region, Asia, North and South America and the European Union, but the highest dynamics of crop production area increase is recorded in the countries of the Black Sea region, Africa and South Asia. The area of coarse grains cultivation has increased in East Asia and South America. The largest producer of grain is the European Union, but Asian countries have also increased grain production. The highest growth rates in crops output were observed in the countries of the Black Sea region, Africa, South America and East Asia. Wheat production has increased in all regions except Oceania and North America. Regarding coarse grains, the largest producers are North America, East Asia and the European Union. Higher rates of grain production are recorded in South America, East and Southeast Asia.

The largest wheat producer of in the world is the European Union, but its advantage over other countries will continue to decline. China and India are expected to take first place. The countries of the Black Sea region and the USA are also important wheat producers, however, the highest increase among the top ten producers is observed in Ukraine. The main producers of coarse grains are the United States, China and the European Union.

Changes in the area of sowings, sets and crops were presented. Directions of allocating cereal crops in the last period were compared. The directions of changes on the market of cereal crops in Ukraine were identified. In Ukraine the area of the cultivation and the level of sets were stable. In Ukraine, over the past period the upward trend in gross grain production has been observed and is forecasted to remain as such for the next 10-15 years. The share of more productive plants, such as corn, has increased in the structure of cereals, with a simultaneous decrease in the yield of rye and grain mixtures. In line with the increase in production volumes, grain exports from Ukraine have also increased, which will increase the inflow of foreign currency into the country.

The grain subcomplex has considerable development potential, which will improve the economic situation not only in agriculture, but also in the country's economy as a whole. However, the grain subcomplex capacity building and its further development should take place in the context of the developed state policy to support the agricultural sector and, in particular, the grain sector. The key focus for the development of grain market in Ukraine is its export expansion.

Key words: entrepreneurship production of cereals, grain market, grain farming, coarse grains,cultivation.

Дата надходження до редакції: 03.01.2019 р. 